\title{
Appearance of Dinophysis fortii following blooms of certain cryptophyte species
}

\author{
Kazuhiko Koike ${ }^{1,3, *}$, Asami Nishiyama ${ }^{1}{ }$ Kiyotaka Takishita ${ }^{2}$, \\ Atsushi Kobiyama ${ }^{1}$, Takehiko Ogata ${ }^{1}$
}

\begin{abstract}
${ }^{1}$ Kitasato University, School of Fisheries Sciences, 160-4 Aza-Uhoh, Okirai, Sanriku, Ofunato, Iwate 022-0101, Japan
${ }^{2}$ Japan Agency for Marine-Earth Science and Technology, Extremobiosphere Research Center, Research Program for Marine Biology and Ecology, 2-15 Natsushima, Yokosuka, Kanagawa, 237-0061, Japan
\end{abstract}

${ }^{3}$ Present address: Hiroshima University, Graduate School of Biosphere Science, 1-4 Kagamiyama, Higashi-Hiroshima, Hiroshima 739-8528, Japan

\begin{abstract}
We examined the possibility that dinoflagellates belonging to genus Dinophysis acquire plastids from certain species of cryptophytes. We measured the abundance of cryptophytes over a 3 yr period in Okkirai Bay, northern Japan by fluorescent in situ hybridization (FISH), using an oligonucleotide probe that specifically binds to the Dinophysis plastid small subunit ribosomal RNA. A high density of FISH-probed cryptophytes always occurred prior to peak occurrences of $D$. fortii, although the density of FISH-probed cryptophytes did not correlate well with the density of $D$. fortii. Although further investigation is needed, monitoring of these cryptophyte species may be useful for predicting Dinophysis growth and subsequent outbreaks of diarrhetic shellfish poisoning.
\end{abstract}

KEY WORDS: Dinophysis $\cdot$ Diarrhetic shellfish poisoning $\cdot$ Cryptophyte $\cdot$ Teleaulax $\cdot$ Fluorescent in situ hybridization

- Resale or republication not permitted without written consent of the publisher

\section{INTRODUCTION}

The dinoflagellate genus Dinophysis includes species known to produce lipophilic shellfish toxins (Yasumoto et al. 1985) and cause diarrhetic shellfish poisoning (DSP). The genus includes both photosynthetic and non-photosynthetic (heterotrophic) species. The former are known to possess a peculiar phycoerythrin-containing plastid with a double membrane and a 2-layered thylakoid (Schnepf \& Elbrächter 1988, Lucas \& Vesk 1990, Berland et al. 1995, Carpenter et al. 1995), which is a characteristic of cryptophytes but not of plastids from typical peridinin-containing dinoflagellates. Therefore, the Dinophysis plastid is thought to originate from a cryptophyte. Because there are no other organelles that could originate from cryptophytes in Dinophysis cells, establishment of the partnership is considered to be an ancient evolutionary event (Lucas \& Vesk 1990, Schnepf \& Elbrächter 1999). Recently, however, analysis of plastid- encoded genes from Dinophysis spp. have supported the opposite view - that the the enosymbiosis is not ancient, but plastids are, instead, transiently acquired from certain cryptophyte species occurring in the surrounding environment (Takishita et al. 2002, Janson 2004, Takahashi et al. 2005, Minnhagen \& Janson 2006). Despite this finding, there remain arguments for an as yet unidentified mechanism for plastid incorporation. If the plastids are transiently acquired from cryptophytes as hypothesized, the occurrence of cryptophytes in the environment should be critical for the growth of Dinophysis spp., because Dinophysis cells tend to be filled with plastids during bloom events (Koike 2002). Furthermore, this would mean that monitoring the relevant cryptophytes would be useful for predicting DSP outbreaks.

In our previous study, we analyzed nucleotide sequences of the plastid-encoded small subunit ribosomal RNA (SSU rRNA) gene (Takishita et al. 2002) and a gene encoding the large subunit of ribulose-1,5- 
bisphosphate carboxylase/oxygenase (rbcL) from 4 species of Dinophysis ( $D$. acuminata, D. fortii, $D$. norvegica, and D. tripos) (Takahashi et al. 2005). We found these sequences to be completely identical among the species, and positioned within the cryptophyte lineage. This indicates that the plastids of these species are probably derived from certain cryptophyte species. We then developed fluorochrome-labeled oligonucleotide probes specific to the plastid of Dinophysis spp. (Takahashi et al. 2005) to detect the plastid origin. In a preliminary trial of fluorescent in situ hybridization (FISH) using one of the probes (targeting plastid SSU rRNA) on nano-sized $(<20 \mu \mathrm{m})$ plankton collected from the field, the probe bound to plastids in cryptophyte-like cells (Takahashi et al. 2005). This suggested that Dinophysis spp. plastids originate from certain types of cryptophytes occurring in seawater.

This finding encouraged us to monitor the density of both FISH-probed cryptophyte-like cells and Dinophysis spp. over an extended period. We report here the results of $3 \mathrm{yr}$ of monitoring in Okkirai Bay, northern Japan, and we compare the abundances of FISHprobed cryptophytes and of Dinophysis fortii, which causes toxin contamination of scallops cultivated in this area.

\section{MATERIALS AND METHODS}

Since 1996, we have conducted weekly sampling at a station in Okkirai Bay $\left(39^{\circ} 05^{\prime} 57^{\prime \prime} \mathrm{N}, 141^{\circ} 51^{\prime} 21^{\prime \prime} \mathrm{E}\right.$; depth $26 \mathrm{~m}$ ) in Iwate Prefecture. The samples from the routine monitoring are described in our previous report (Koike et al. 2001). Briefly, the report gives vertical profiles of water temperature, salinity, inorganic nutrient concentrations ( $\mathrm{N}: \mathrm{NO}_{3}{ }^{-}+\mathrm{NO}_{2}{ }^{-}, \mathrm{NH}_{4}{ }^{+} ; \mathrm{P}: \mathrm{PO}_{4}{ }^{3-}$; $\mathrm{Si}: \mathrm{SiO}_{4}{ }^{4-}$ ), and Dinophysis spp. densities.

In 2003, 2004, and 2005, we performed FISH using a fluorescein isothiocyanate (FITC)-labeled oligonucleotide probe (D16P-1) that is designed to bind specifically to SSU rRNA in the Dinophysis plastid (Takahashi et al. 2005). The samples were taken between April or May

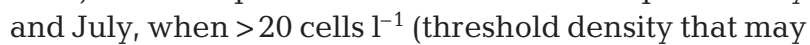
activate a ban on shellfish harvesting in this area) of $D$. fortii are present in the bay. Waters from depths of 0,10 , and $20 \mathrm{~m}$ were collected with a Van Dorn bottle and immediately sieved through a plankton net with a $20 \mu \mathrm{m}$ mesh. Five ml aliquots of the filtrates were fixed with 45 $\mathrm{ml}$ of fixative (a mixture of $37.5 \mathrm{ml} 90 \%$ ethanol, $3 \mathrm{ml}$ $\mathrm{H}_{2} \mathrm{O}$, and $4.5 \mathrm{ml}$ of $25 \times \mathrm{SET}$ buffer [3.75 M NaCl, $25 \mathrm{mM}$ EDTA, $0.5 \mathrm{M}$ Tris- $\mathrm{HCl}, \mathrm{pH} 7.8]$ ) and stored at $-25^{\circ} \mathrm{C}$. Further preparation of the specimens is described in detail in our previous report (Takahashi et al. 2005). Briefly, $25 \mathrm{ml}$ of the fixed samples were vacuumfiltered, and the plankton was trapped with a polycarbonate fil- ter (K080A013A; Advantec). The plankton on the filter was then hybridized with the D16P-1 probe. Finally, a solution of DNA stain (4',6-diamidino-2-phenylindole [DAPI]) was applied to the filter to determine whether the FISH-probed particles were eukaryotic cells. As a positive control, we performed FISH using another probe (G16P-1; Takahashi et al. 2005) targeting the same region of SSU rRNA of the cryptophyte Geminigera cryophila, along with a similarly prepared sample of G. cryophila culture (Marine Biotechnology Institute culture collection; MBIC10567).

We compared the amount of FISH-probed cryptophytes and the total amount of cryptophytes for the period between April 2004 and March 2005. For total cryptophyte counting, filtrates from samples collected from depths of 0,10 , and $20 \mathrm{~m}$ were passed through a $20 \mu \mathrm{m}$ mesh and fixed with glutaraldehyde (final concentration $=1 \%$ ). A $5 \mathrm{ml}$ aliquot was vacuum-filtered through a $0.20 \mu \mathrm{m}$ polycarbonate filter (K020A013A; Advantec) to collect the plankton, and the filter was mounted on a glass slide with a drop of microscope immersion oil (Olympus). Using an epi-fluorescence microscope (BX-40 RFA; Olympus) with green light excitation (510 to $550 \mathrm{~nm}$ ), we counted the total number of cryptophytes for the whole area of the filter, based on the characteristic orange fluorescence emitted by phycobilin pigment and the sizes of the fluorescent particles (Koike et al. 2001).

To obtain an index of plastid volume in Dinophysis fortii, we monitored the in vivo fluorescence intensity of phycobilin pigment in the cells. For all samples, a plankton net (30 cm opening; $20 \mu \mathrm{m}$ mesh) was hauled vertically from a depth of $20 \mathrm{~m}$ to the surface. D. fortii cells in the sample were isolated with a capillary pipet and transferred to several wells of 6 -well plates $(35 \mathrm{~mm}$ inner diameter, $16 \mathrm{~mm}$ deep; Greiner Bio-One) each containing $5 \mathrm{~m}$ of filtered seawater. Within $24 \mathrm{~h}$ of isolation, the plate was observed under an inverted microscope (IX 71; Olympus), and the in vivo fluorescent spectrum (495 to $700 \mathrm{~nm}$ ) emitted from single cells under blue light excitation (460 to $495 \mathrm{~nm}$ ) was collected one cell at a time (total of 10 to 20 cells) using a micro-photonic spectrometer (PMA-11; Hamamatsu Photonics) connected to the eyepiece port of the microscope. Each cell occupied almost $90 \%$ of the detection area when using a $40 \times$ objective lens. From the spectra obtained from each cell, we estimated the height of the emission peak at approximately 580 to $600 \mathrm{~nm}$, which is characteristic for phycoerythrin.

\section{RESULTS}

Using the FISH procedure, we found cells showing FITC (green) fluorescence on the plastid and DAPI 

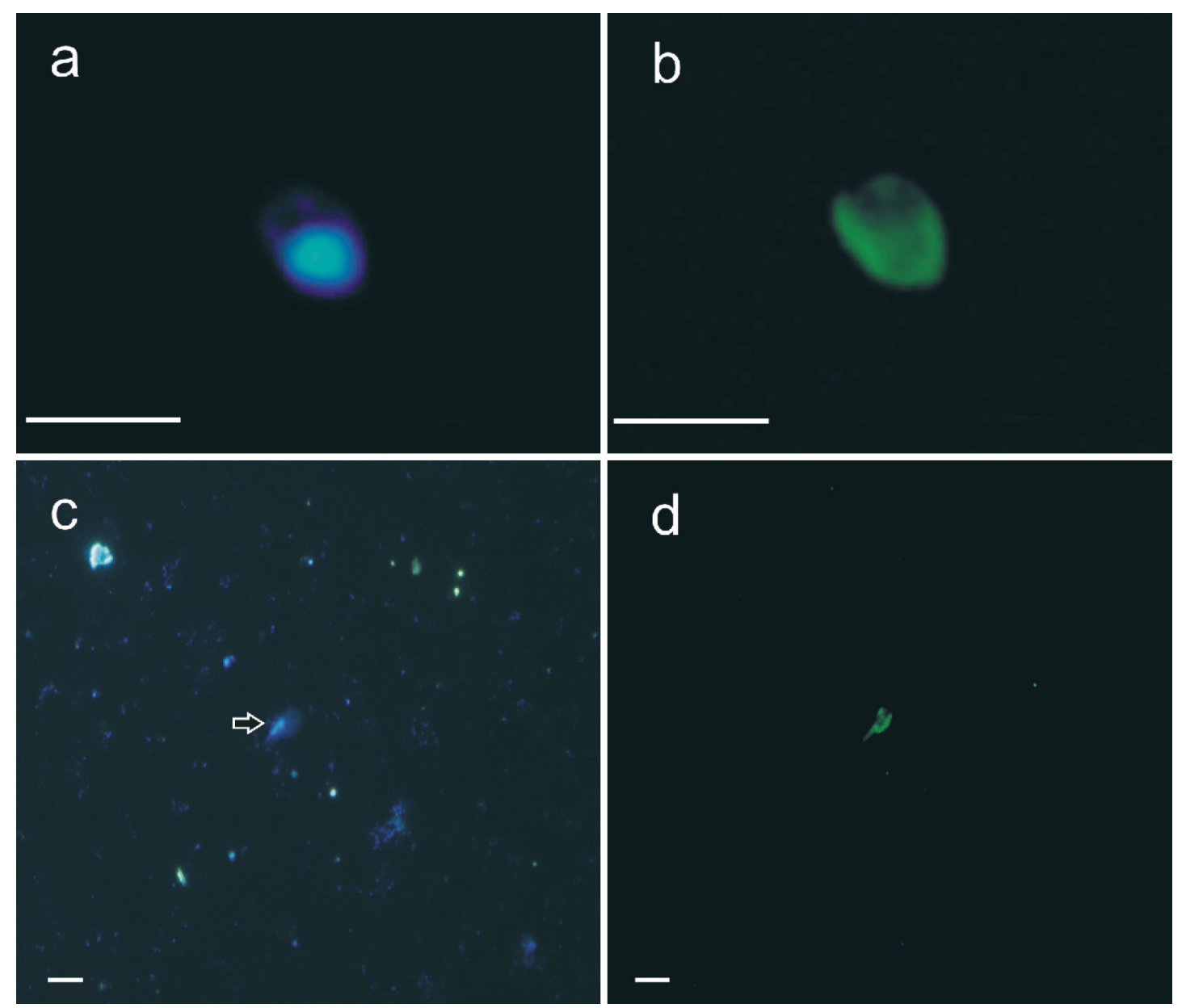

Fig. 1. Fluorescence micrographs of cryptophytes. Left column, UV-excited fluorescence microscopy after staining DNA with DAPI; right column, blue-excited fluorescence microscopy after in situ hybridization using an FITC-labeled oligonucleotide probe (D16P-1). (a, b) A cryptophyte-like cell showing clear probe binding to the plastid. A DAPI-stained nucleus is located in the hollow of the plastid vent, which is characteristic of cryptophytes. (c, d) Even among the DAPI-stained particles, the FITC-labeled cryptophyte can be recognized. The arrow in (c) indicates the cryptophyte nucleus. Scale bars $=10 \mu \mathrm{m}$

(blue) fluorescence on the nucleus (Fig. 1). Based on the characteristic V-shape of the plastid, the position of the nucleus at the hollow of the plastid bend, and the binding specificity of the probe (Takahashi et al. 2005), these cells appeared to be cryptophytes. These could be discerned amongst the miscellaneous plankters (Fig. 1c,d).

In the field, the FISH-probed cryptophytes (FPCs) always appeared suddenly. They increased between the end of May and the beginning of June. In 2003, FPCs occurred in low numbers at $10 \mathrm{~m}$ depth on May 31, peaked on June 4 at a density of 3200 cells $^{-1}$, and then disappeared (Fig. 2). This sudden appearance was most notable in 2004; FPCs surged at $20 \mathrm{~m}$ depth on May 26 at peak density of 109200 cells $^{-1}$, and almost disappeared thereafter (Fig. 3). Also, in 2005, FPCs suddenly peaked at $10 \mathrm{~m}$ depth on May 24 at density of

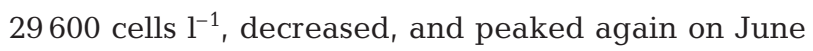
15 and 21 at all depths (Fig. 4); however, the decreases were gradual compared to previous years. Among the layers, FPCs were most sparse at the surface $(0 \mathrm{~m})$. In the survey between April 2004 and March 2005, FPCs were suddenly detected in the bay during a particular period in May or June, whereas cryptophytes were detected throughout the year (Fig. 5).

There was an apparent relationship between the peaks of FPC and Dinophysis fortii occurrences. In both 2003 (Fig. 2) and 2005 (Fig. 4), the occurrence of $D$. fortii began to increase after several days of FPC peaks, and in 2004 (Fig. 3), D. fortii showed a sudden increase on the same day as the FPC peak. Also, the occurrence of $D$. fortii showed multiple peaks in 2005 when FPCs were present for a prolonged period (Fig. 4). Nevertheless, the densities of FPCs did not 


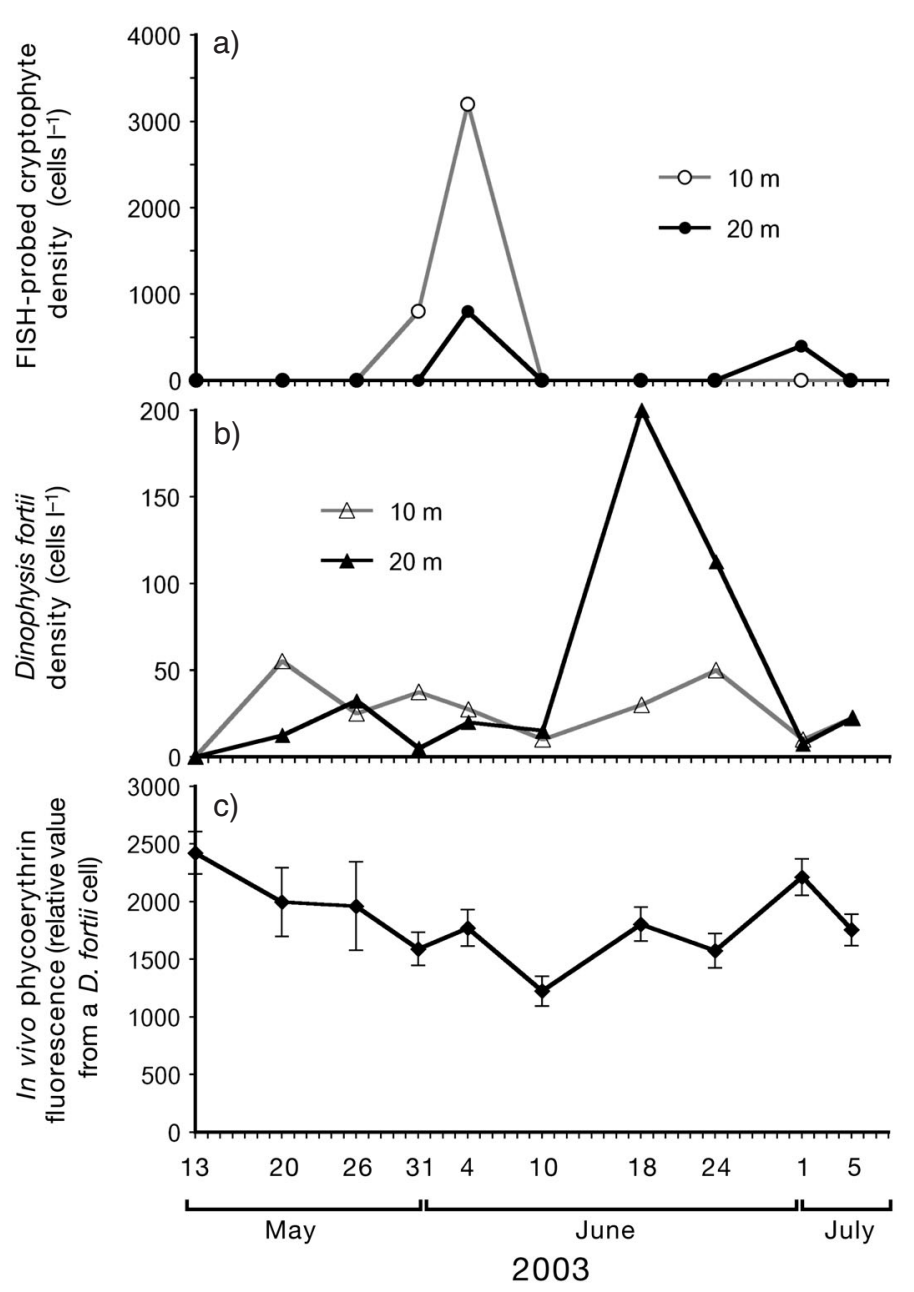

Fig. 2. (a) Temporal changes in the abundance of FISHprobed cryptophytes, as measured with D16P-1 probe, and (b) Dinophysis fortii in Okkirai Bay in 2003. Samples were collected from depths of $10 \mathrm{~m}(\mathrm{O}, \Delta)$ and $20 \mathrm{~m}(\boldsymbol{\bullet}, \boldsymbol{\Delta})$. (c) The relative in vivo fluorescence value of phycoerythrin pigment from a $D$. fortii cell; mean \pm SD, $n=10$ to 20 cells

always correlate with those of $D$. fortii. The maximum density of $D$. fortii $\left(200\right.$ cells l $^{-1}$ ) was recorded in 2003, when FPCs occurred in low numbers, whereas, in 2004 , the density of $D$. fortii was almost the same when the density of FPCs was 30 -fold higher than in 2003. In

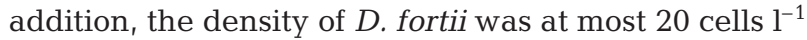
in 2005, despite the fact that the density of FPCs was 10 -fold higher than in 2003. Also, there seemed to be no apparent relationship between the occurrence of FPCs and the intensities of in vivo phycoerythrin fluorescence in $D$. fortii cells. Although it seemed that the fluorescence intensity almost doubled for the week between 20 and 26 May 2004, when there was an extremely high density of FPCs (Fig. 3), such a relationship was not observed in either 2003 or 2005 (Figs. $2 \& 4$ ).

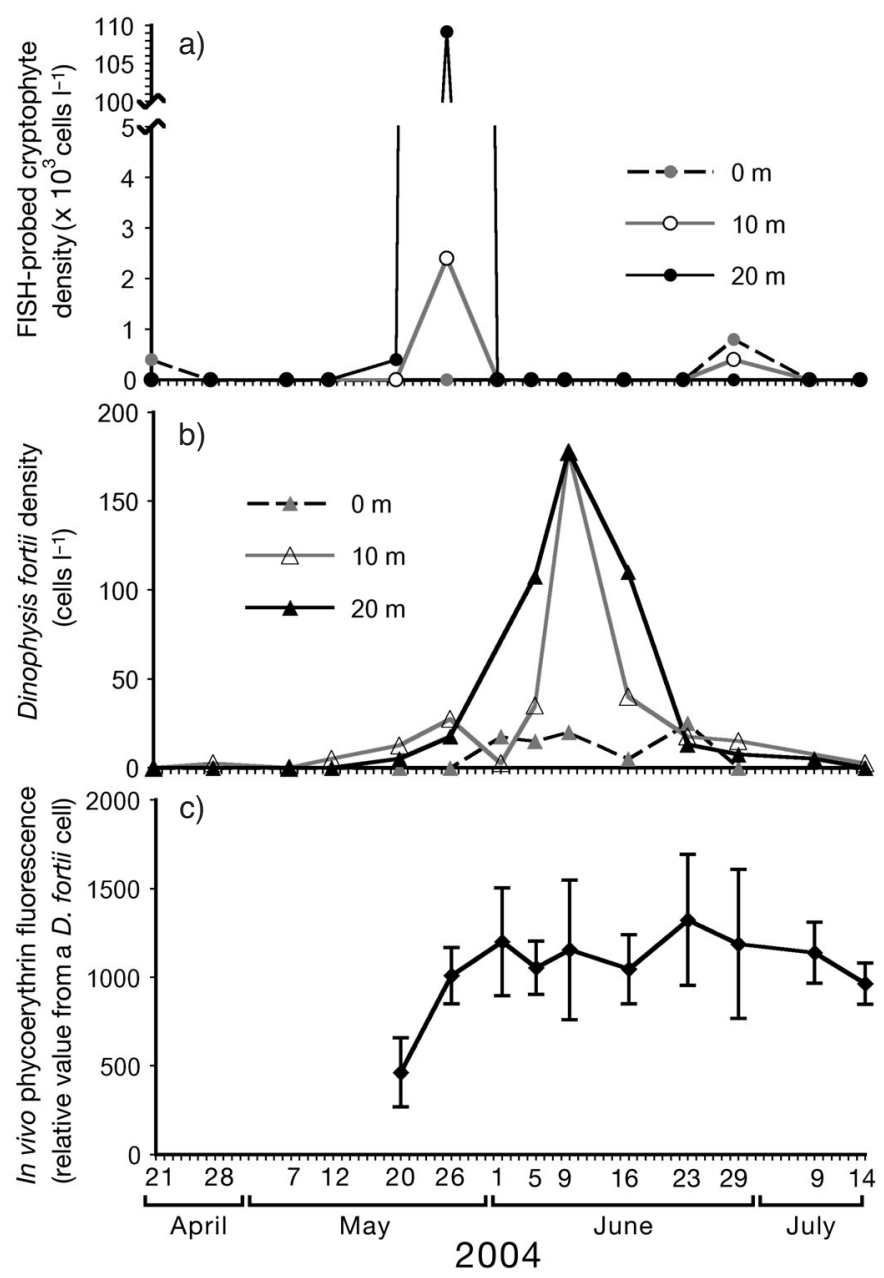

Fig. 3. (a) Temporal changes in the abundance of FISHprobed cryptophytes, as measured with D16P-1 probe, and (b) Dinophysis fortii in Okkirai Bay in 2004. Samples were collected at depths of $0 \mathrm{~m}(\boldsymbol{\odot}, \Delta), 10 \mathrm{~m}(\mathrm{O}, \Delta)$, and $20 \mathrm{~m}(\boldsymbol{\bullet}, \boldsymbol{\Delta})$.

(c) The relative in vivo fluorescence value of phycoerythrin pigment from a $D$. fortii cell; mean $\pm \mathrm{SD}, \mathrm{n}=10$ to 20 cells

\section{DISCUSSION}

Whether the plastids of Dinophysis spp. result from a permanent symbiosis with a cryptophyte or transient acquisition from cryptophytes in the environment has been long discussed; however, the issue remains controversial. The plastid of Dinophysis spp. is surrounded by 2 layers of plastid membranes (Schnepf \& Elbrächter 1988) and differs from that of cryptophytes, which are surrounded by an additional 2 layers of plastid endoplasmic reticulum. There are also no remnants from cryptophytes in the Dinophysis cytoplasm other than the plastids. Therefore, the acquisition of the plastid from cryptophytes has been considered an ancient evolutionary event (Lucas \& Vesk 1990, Schnepf \& Elbrächter 1999). However, a heterotrophic species ( $D$. 


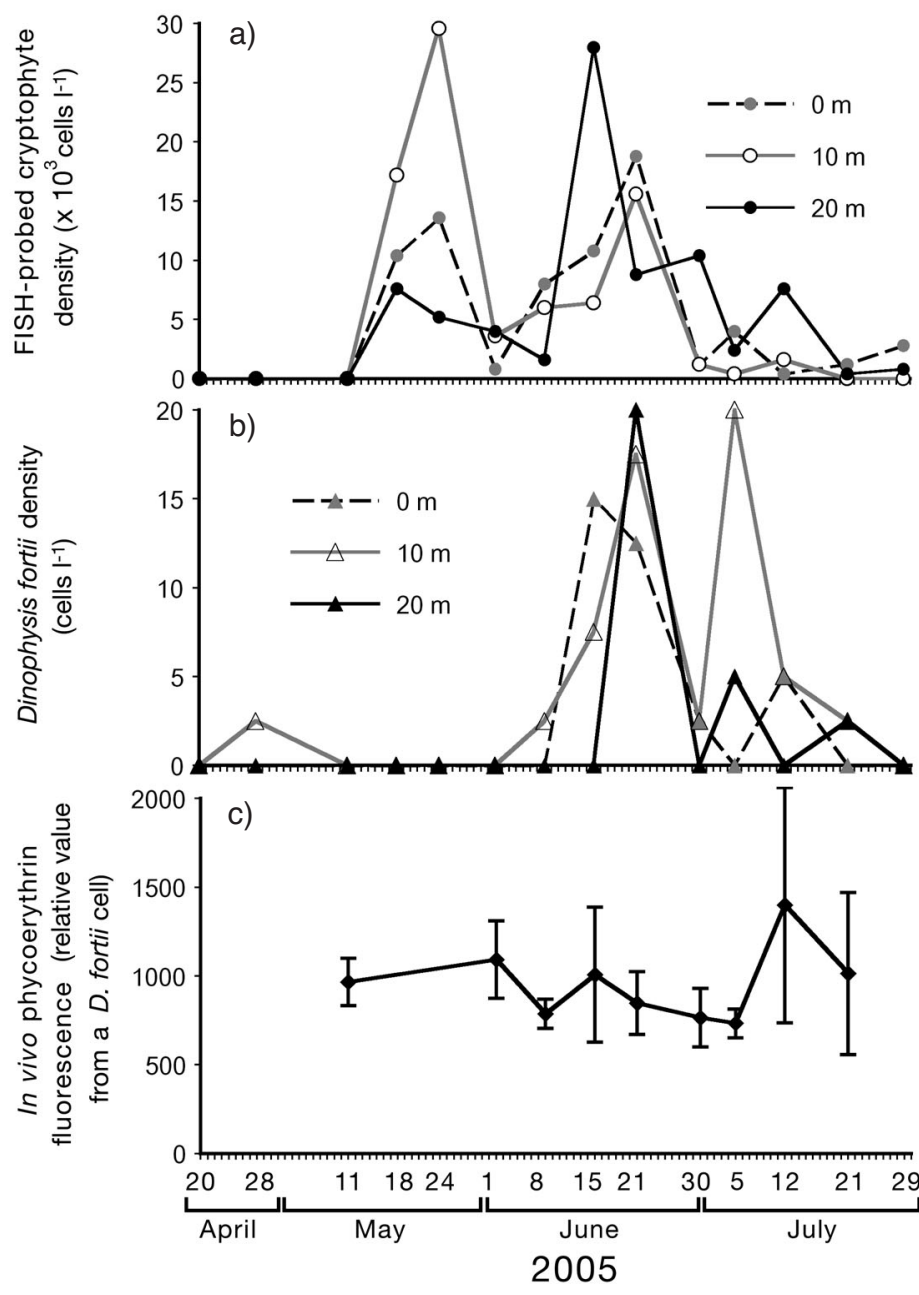

Fig. 4. (a) Temporal changes in the occurrence of FISHprobed cryptophytes, as measured with D16P-1 probe, and (b) Dinophysis fortii in Okkirai Bay in 2005. Samples were collected at depths of $0 \mathrm{~m}(\mathbf{O}, \Delta), 10 \mathrm{~m}(\mathrm{O}, \Delta)$, and $20 \mathrm{~m}(\boldsymbol{\bullet}, \boldsymbol{\Delta})$.

(c) Relative in vivo fluorescence value of phycoerythrin pigment from a $D$. fortii cell; mean $\pm \mathrm{SD}, \mathrm{n}=10$ to 20 cells

mitra) acquires plastids from haptophytes and then degrades the outer endoplasmic reticulum while selectively retaining the plastid membranes (Koike et al. 2005); hence, the characteristics of the membrane system are not always an adequate indicator of whether the plastids are permanent or transiently acquired.

Furthermore, analysis of the SSU rRNA gene of plastids from a variety of Dinophysis species shows that they are: (1) uniform among the species, whereas there are species-specific base substitutions in the nuclear sequences (Takishita et al. 2002); and (2) they are identical to that of the extant cryptophyte species Teleaulax amphioxeia (Janson 2004). Considering the fact that the sequences from fully established dinoflagellate plastids (containing peridinin and fucoxanthin derivatives) have a higher rate of evolution than the nuclear genes (Zhang et al. 1999, 2000, Barbrook \& Howe 2000, Tengs et al. 2000), the plastids in Dinophysis spp. are more likely kleptoplasts (temporarily 'stolen' plastids, also known as kleptoplastids) acquired from specific species of cryptophytes occurring in the surrounding environment.

To prove the acquisition of plastids from cryptophytes, we developed molecular probes that specifically recognize the Dinophysis plastid, and hence the plastids of specific cryptophyte species (should they be the source of the Dinophysis plastid). Analyses of the phylogenetic relationship between plastid-encoded genes from Dinophysis spp. and cryptophytes (Takishita et al. 2002, Janson 2004, Takahashi et al. 2005, Minnhagen \& Janson 2006) support the idea that the plastids originate from clade B (genera Geminigera, Plagioselmis, and Teleaulax) of the Cryptophyceae (Deane et al. 2002) and, more specifically, from species belonging to the genus Teleaulax (Janson 2004, Takahashi et al. 2005, Minnhagen \& Janson 2006); however, these cryptophytes cannot be precisely identified by their cell shapes. Instead, probes that also bind to the plastids of Teleaulax spp. can be used to follow their occurrence and to clarify the in situ relationship between Dinophysis spp. and Teleaulax spp. Note that our probe was designed to bind to any Teleaulax species, on the basis of what is known from available DNA
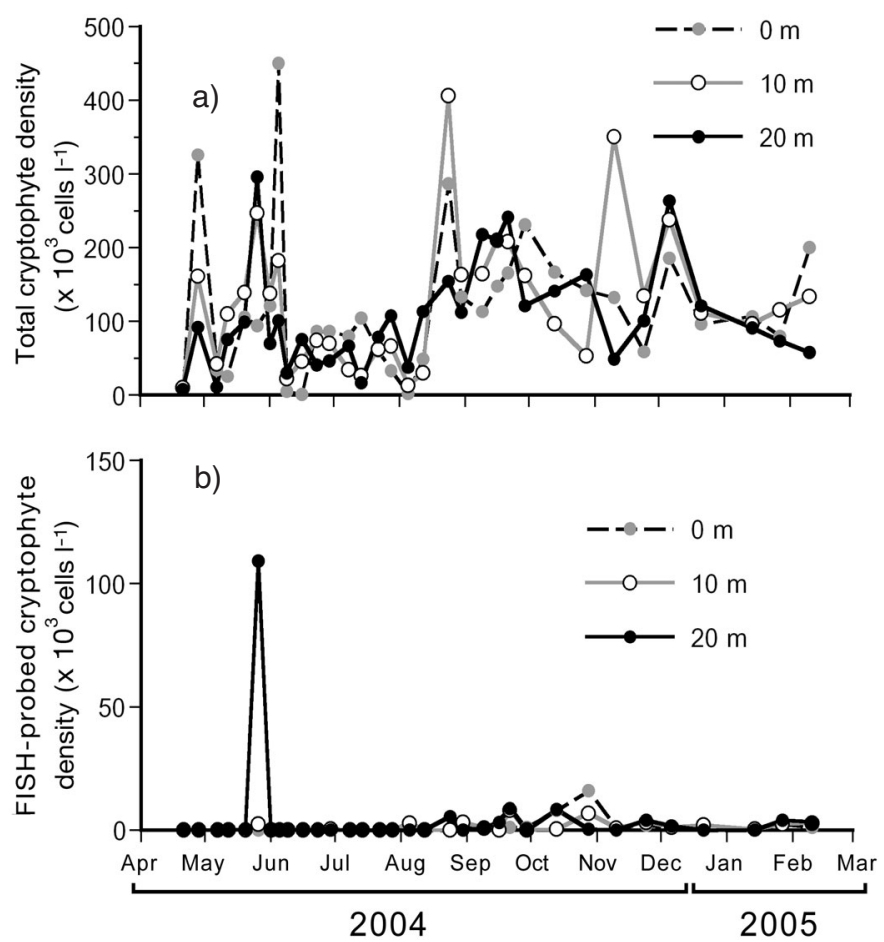

Fig. 5. (a) Temporal change in the abundance of total cryptophytes and (b) FISH-probed cryptophytes at depths of $0 \mathrm{~m}$ (๑), $10 \mathrm{~m}(\mathrm{O})$, and $20 \mathrm{~m}(\mathbf{)})$ in Okkirai Bay between April 2004 and March 2005 
sequences from Teleaulax sp. (GenBank accession no. AB164407) and T. amphioxeia (AY453067).

In this study, we examined the relationship between the abundances of Dinophysis fortii, the most prominent species of Dinophysis spp. in this region, and of the possible source of the Dinophysis plastid. Most intriguingly, using FISH, we identified cryptophytes, possibly Teleaulax spp., in the field, and we found that the density of $D$. fortii began to increase just after the FISH-probed cryptophytes appeared. Because this held for all 3 yr of the study, it is reasonable to hypothesize that $D$. fortii takes up Teleaulax spp. and then grows, due to the acquired photosynthetic ability. Recently, Park et al. (2006) found that D. acuminata preyed on an oligotrich ciliate Myrionecta rubra fed with Teleaulax sp. Therefore, recruiting the plastid via such ciliates may be plausible. Alternatively, as suggested by Nishitani et al. (2002), Dinophysis spp. may even take up picophytoplankton directly. Although we can not conclude yet that this is the incorporation mechanism, Dinophysis plastids seem to originate ultimately from Teleaulax. Ours is the first evidence showing that the occurrence of Teleaulax coincides well with that of $D$. fortii, suggesting that $D$. fortii takes up Teleaulax directly or indirectly.

The abundance of Teleaulax spp. differed each year, but the cryptophyte always appeared prior to the

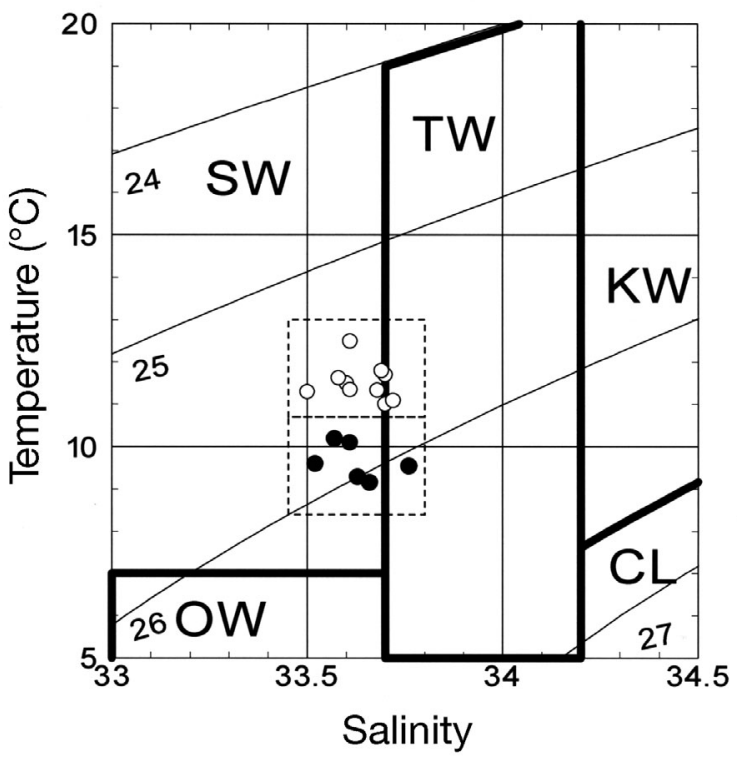

Fig. 6. Temperature-salinity (TS) scatter plot (Hanawa \& Mitsudera 1987) of data collected when Dinophysis fortii was at peak abundance (data from regular surveys during 1995-2005; O) and of FISH-probed cryptophyte peaks detected in this study $(2003-2005 ; 0)$. TW = Tsugaru Warm Current water; OW = Oyashio cold water; $\mathrm{CL}=$ cold lower-layer water; $\mathrm{SW}=$ coastal surface-layer water; $\mathrm{KW}=$ Kuroshiro warm water; values on diagonal curves are seawater density $\sigma_{\mathrm{t}}\left(\mathrm{kg} \mathrm{m}^{-3}\right)$ appearance of Dinophysis fortii. Therefore, monitoring Teleaulax may help predict $D$. fortii growth and subsequent outbreaks of DSP. Note that the abundances of $D$. fortii within the study period (2003 to 2005) were rather low, but above 20 cells $\mathrm{l}^{-1}$, which would cause significant toxin accumulation in bivalves in this area (Koike et al. 2001).

To elucidate the environmental conditions that lead to an increase in Teleaulax abundance, we prepared a bivariate scatter plot of temperature and salinity when the peak abundances of Teleaulax spp. were observed (Fig. 6). The study area (Sanriku Coast) is greatly influenced by a complicated water system consisting of the Tsugaru Warm Current water (TW), Oyashio cold water (OW), a cold lower-layer water (CL) and a coastal surface-layer water (SW). By presenting the temperature and salinity (TS) data in the scatter plot designed by Hanawa \& Mitsudera (1987), the dynamics of the water system can be understood well. Using samples from our regular monitoring from 1995 to 2005, the TS data coordinates for the period when Dinophysis fortii peaked are clustered within a very narrow range. This coordinate range occurs where there is a mixing of coastal surfacelayer water (SW) and Tsugaru Warm Current water (TW) (O, in Fig. 6). TS data coordinates for the period when Teleaulax peaked (data obtained in this study) also clustered within a similar narrow range, but at somewhat lower temperatures (•, in Fig. 6). This indicates that the water mass containing Teleaulax peak abundances was also formed by a mixing of SW and TW, but earlier in the season than when $D$. fortii peaked. Hence, the factor most likely promoting the occurrence of $D$. fortii in this specific water mass is the abundance of Teleaulax earlier in the season.

Cell density of Dinophysis fortii did not reflect the density of Teleaulax. This might be due to a temporal sampling regime that missed peaks of cryptophyte abundance (the appearance of Teleaulax spp. was always very transient), or because we sampled at discrete depths through the water column. The daily vertical migration of Dinophysis (Durand Clement et al. 1988) may also play a role. Alternatively, plastid acquisition may become saturated so that a threshold density of Teleaulax spp. earlier in the season may be sufficient to cause a subsequent growth of Dinophysis spp., as indicated above. More intensive and longer term sampling, preferably in other regions with different Dinophysis spp., is needed to explore this further. In addition, it is always necessary to take into account heterotrophic growth of photosynthetic Dinophysis spp., as recently demonstrated by Park et al. (2006), and especially by Jacobson \& Anderson (1994) and Koike et al. (2000). 
Acknowledgements. This work was supported by a Grant-inAid (No. 17380125) for Scientific Research from the Ministry of Education, Culture, Sports, Science, and Technology of Japan (to K.K.) and by the Multilateral Cooperative Research Program ('Ecology and Oceanography of Harmful Microalgae in the Southeast Asian Region, Coastal Oceanography') of the Japan Society for the Promotion of Science.

\section{LITERATURE CITED}

Barbrook AC, Howe CJ (2000) Minicircular plastid DNA in the dinoflagellate Amphidinium operculatum. Mol Gen Genet 263:152-158

Berland BR, Maestrini SY, Grzebyk D, Thomas P (1995) Recent aspects of nutrition in the dinoflagellate Dinophysis cf. acuminata. Aquat Microb Ecol 9:191-198

Carpenter EJ, Janson S, Boje R, Pollehne F, Chang J (1995) The dinoflagellate Dinophysis norvegica: biological and ecological observations in the Baltic Sea. Eur J Phycol 30: $1-9$

Deane JA, Strachan IM, Saunders GW, Hill DRA, McFadden GI (2002) Cryptomonad evolution: nuclear 18S rDNA phylogeny versus cell morphology and pigmentation. J Phycol 38:1236-1244

Durand Clément $\mathrm{M}$, Clément JC, Moreau A, Jeanne N, Puiseux-Dao S (1988) New ecological and ultrastructural data on the dinoflagellate Dinophysis sp. from the French coast. Mar Biol 97:37-44

Hanawa K, Mitsudera H (1987) Variation of water system distribution in the Sanriku coastal area. J Oceanogr Soc Jap 42:435-446

Jacobson DM, Andersen RA (1994) The discovery of mixotrophy in photosynthetic species of Dinophysis (Dinophyceae): light and electron microscopical observations of food vacuoles in Dinophysis acuminata, $D$. norvegica and two heterotrophic dinophysoid dinoflagellates. Phycologia 33:97-110

Janson S (2004) Molecular evidence that plastids in the toxinproducing dinoflagellates genus Dinophysis originate from the free-living cryptophyte Teleaulax amphioxeia. Environ Microbiol 6:1102-1106

Koike K (2002) Mixotrophy of Dinophysis fortii: a strategy for growth in various environmental conditions. Fish Sci 68 (Suppl 1):529 -532

Koike K, Koike K, Takagi M, Ogata T, Ishimaru T (2000) Evidence of phagotrophy in Dinophysis fortii (Dinophysiales, Dinophyceae), a dinoflagellate that causes diarrhetic shellfish poisoning (DSP). Phycological Res 48:121-124

Koike K, Otobe H, Takagi M, Yoshida T, Ogata T, Ishimaru T (2001) Recent occurrences of Dinophysis fortii (Dino-

Editorial responsibility: Howard Browman (Associate Editorin-Chief), Storebø, Norway phyceae) in the Okkirai bay, Sanriku, Northern Japan, and related environmental factors. J Oceanogr 57: 165-175

Koike K, Sekiguchi H, Kobiyama A, Takishita K, Kawachi M, Koike K, Ogata T (2005) A novel type of kleptoplastidy in Dinophysis (Dinophceae): presence of haptophyte-type plastid in Dinophysis mitra. Protist 156:225-237

Lucas IAN, Vesk M (1990) The fine structure of two photosynthetic species of Dinophysis (Dinophysiales, Dinophyceae). J Phycol 26:345-357

Minnhagen S, Janson S (2006) Genetic analyses of Dinophysis spp. support kleptoplastidy. FEMS Microbiol Ecol 57: $47-54$

Nishitani G, Sugioka H, Imai I (2002) Seasonal distribution of species of the toxic dinoflagellate genus Dinophysis in Maizuru Bay (Japan), with comments on their autofluorescence and attachment of picophytoplankton. Harmful Algae 1:253-264

Park MG, Kim S, Kim HS, Myung G, Kang YG, Yih W (2006) First successful culture of the marine dinoflagellate Dinophysis acuminata. Aquat Microb Ecol 45:101-106

Schnepf E, Elbrächter M (1988) Cryptophycean-like doublemembrane bounded chloroplast in the dinoflagellate, Dinophysis Ehrenb. Evolutionary, phylogenetic and toxicological implications. Bot Acta 101:196-203

Schnepf E, Elbrächter M (1999) Dinophyte chloroplasts and phylogeny: a review. Grana 38:81-97

Takahashi Y, Takishita K, Koike K, Maruyama T, Nakayama T, Kobiyama A, Ogata T (2005) Development of molecular probes for Dinophysis (Dinophyceae) plastid: a tool to predict blooming and explore plastid origin. Mar Biotechnol 7:95-103

Takishita K, Koike K, Maruyama T, Ogata T (2002) Molecular evidence for plastid robbery (kleptoplastidy) in Dinophysis, a dinoflagellate causing diarrhetic shellfish poisoning. Protist 153:293-302

Tengs T, Dahlberg OJ, Shalchian-Tabrizi K, Klaveness D, Rudi K, Delwiche CF, Jakobsen KS (2000) Phylogenetic analyses indicate that the 19 'hexanoyloxy-fucoxanthincontaining dinoflagellates have tertiary plastids of haptophyte origin. Mol Biol Evol 17:718-729

Yasumoto T, Murata M, Oshima Y, Sano M, Matsumoto GK, Clardy L (1985) Diarrhetic shellfish toxins. Tetrahedron 41:1019-1025

Zhang Z, Green BR, Cavalier-Smith T (1999) Single gene circles in dinoflagellate chloroplast genomes. Nature 400: $155-159$

Zhang Z, Green BR, Cavalier-Smith T (2000) Phylogeny of ultra-rapidly evolving dinoflagellate chloroplast genes: a possible common origin for sporozoan and dinoflagellate plastids. J Mol Evol 51:26-40

Submitted: July 26, 2006; Accepted: November 22, 2006 Proofs received from author(s): May 7, 2007 